地 震 第 2 輯

第 61 巻特集号（2009） S199-S207 頁

\section{レシーバ関数解析による 地震波速度不連続構造}

\author{
京都大学防災研究所 * \\ 涉谷拓 郎
}

京都大学大学院理学研究科 $* *$

平 原 和 朗

\section{防災科学技術研究所 *** \\ 上野友岳}

\section{Receiver Function Analyses for Estimating Seismic Velocity Discontinuity Structure}

\section{Takuo SHIBUTANI}

Disaster Prevention Research Institute, Kyoto University, Gokasho, Uji, Kyoto 611-0011, Japan

\section{Kazuro HiraHara}

Graduate School of Science, Kyoto University, Kitashirakawa, Sakyo-ku, Kyoto 606-8502, Japan

Tomotake UENO

National Research Institute for Earth Science and Disaster Prevention, 3-1 Tennodai, Tsukuba, Ibaraki 305-0006, Japan

(Received May 15, 2008; Accepted November 4, 2008)

Receiver function analyses have been developed since the late 1970s. Receiver functions are calculated by deconvolving the vertical component from the horizontal components of teleseismic $\mathrm{P}$ waveforms in order to remove the complexities of the source time functions and to extract the structural information beneath seismic stations. The receiver functions are sensitive to impedance discontinuities of the earth's interior, especially to the shear wave velocity discontinuities. Therefore, the receiver function analyses have advantages in estimating the shear wave velocity structure and imaging the shear wave velocity discontinuities. In this paper we introduce several basic topics of the receiver function analyses. Firstly, we discuss the method of the calculation of the receiver functions, pointing out weaknesses in the water level method and the multitaper method and introducing the extended-time multitaper method. Secondly, we describe the inversions of the receiver functions for the shear wave velocity structure. We show two examples with the genetic algorithm. Thirdly,

\footnotetext{
*=611-0011 宇治市五ヶ庄

** $=606-8502$ 京都市左京区北白川

${ }^{* * *}$ 干 305-0006 つくば市天王台 3-1
}

we introduce the way and several examples to image the shear wave velocity discontinuities with the use of the receiver functions. Finally, we discuss issues in the receiver function analyses which have not been addressed yet but should be in the near future.

Key words: Receiver function, Extended-time multitaper method, Receiver function inversion, Genetic algorithm, Receiver function imaging

\section{§1.はじめに}

レシーバ関数は, デコンボリューションにより, 遠地 地震の $\mathrm{P}$ 波部分の水平動成分から上下動成分を除去する ことにより算出される [Langston (1979)]. 両成分に共 通に含まれる震源時間関数と観測システムのインパルス レスポンスは，このデコンボリューションにより相殺さ れ, 観測点下の構造の応答特性を抽出することができる. Ammon（1991）は，地震波の入射角が小さく，構造が水 平成層である場合に，このデコンボリューションによっ て P 波の多重反射の寄与が弱められ, PS 変換波が強調 されることを示した，時間領域におけるこの応答特性， すなわちレシーバ関数には, Fig. 1 に示すように, 直達
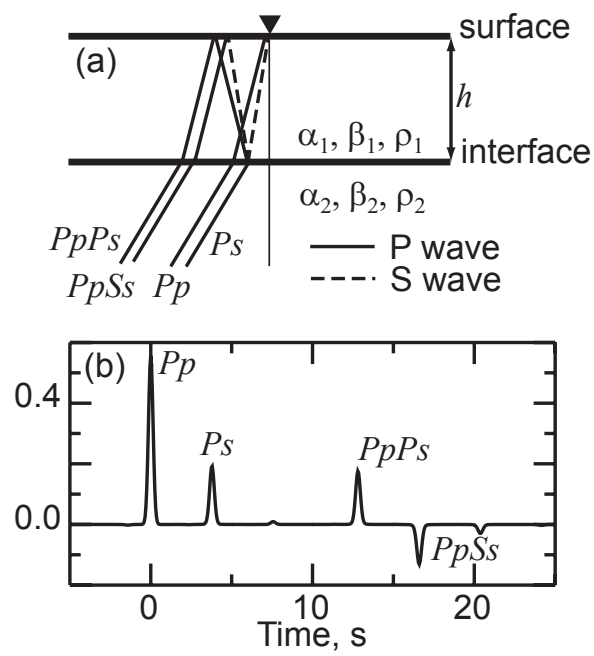

Fig. 1. (a) Schematic illustration showing the ray paths of the four major phases, Pp, Ps, PpPs and PpSs of the radial receiver function shown in (b) in the case of a layer-onhalf-space model. The solid and broken lines indicate $\mathrm{P}$ and $\mathrm{S}$ waves, respectively. $\alpha, \beta$, and $\rho$ are $\mathrm{P}$ and $\mathrm{S}$ velocities and density. The subscripts " 1 " and " 2 " indicate the upper layer and the half space. The thickness of the upper layer is denoted by $h$. (b) Synthetic waveform of the radial receiver function calculated for the model shown in (a) where $\alpha_{1}=6.0 \mathrm{~km} \mathrm{~s}^{-1}, \beta_{1}=3.5 \mathrm{~km} \mathrm{~s}^{-1}, \rho_{1}=2.7 \mathrm{~g} \mathrm{~cm}^{-3}, \alpha_{2}=$ $8.0 \mathrm{~km} \mathrm{~s}^{-1}, \beta_{2}=4.5 \mathrm{~km} \mathrm{~s}^{-1}, \rho_{2}=3.3 \mathrm{~g} \mathrm{~cm}^{-3}, h=30 \mathrm{~km}$ and the slowness is $0.072 \mathrm{~s} \mathrm{~km}^{-1}$. 
$\mathrm{P}$ 波 (Pp) のほかに，観測点下の不連続面での PS 変換波 (Ps) やその多重反射波 (PpPs, PpSs 等) が含まれる。こ れらの PS 変換波と直達 $\mathrm{P}$ 波の走時差は, 変換面の深さ と変換面から観測点までの速度構造によって決まる。ま た, PS 変換波と直達 P 波の振幅比は, 変換面での速度 と密度の不連続量で決まる。ただし, P 波速度の不連続 量はPS 変換波の生成にほとんど寄与しないし，密度の 不連続量は多重反射波の生成に多少寄与する程度であ る.

したがって, 逆にレシーバ関数を解くことによって, 観測点下の速度構造を推定することができる.ここでは, この手法をレシーバ関数インバージョンと呼ぶことにす る.また, 速度構造を仮定して, レシーバ関数の時間軸 を深さ変換し, 多数の観測点で多数の地震に対して得ら れたレシーバ関数の振幅を共通の変換点上で重合するこ とにより, $\mathrm{S}$ 波速度不連続面のイメージを得ることがで きる.ここでは, この手法をレシーバ関数イメージング と呼ぶことにする。

本論文では, 以下に, レシーバ関数の計算法, レシー バ関数インバージョン, レシーバ関数イメージングの順 に解説する.

\section{§2. レシーバ関数の計算法}

前章で述べたようにレシーバ関数は，デコンボリュー ションにより, 水平動成分から上下動成分を除去するこ とによって算出される。このデコンボリューションは, 成分間で相関のないノイズが大きい場合に不安定にな る [Langston and Hammer (2001)]. Langston and Hammer （2001）は，単独の上下動波形の代わりに，複数の観測 点の上下動成分の平均波形を用いると, デコンボリュー ションの不安定さを軽減することができることを示し た. デコンボリューションを不安定にするもうひとつの 要因として, 以下に述べるような波形処理における問題 がある。このデコンボリューションは (1) 式で示すよう に周波数領域における除算で行うことができる.

$$
\frac{H(\omega)}{U(\omega)}=\frac{H(\omega) \widetilde{U}(\omega)}{U(\omega) \widetilde{U}(\omega)}
$$

ここに $H(\omega)$ と $U(\omega)$ はそれぞれ水平動成分と上下動 成分のスペクトルを示す。～は複素共役を示す。（1）式 の分母は上下動成分のパワースペクトルであるが，こ のパワースペクトルにおける小さな值，すなわちスペク トルホールが (1) 式の除算を不安定にする，スペクトル ホールの主要な原因は有限長のデータを扱うことによる スペクトル漏れである. スペクトルホールの影響を減じ るためのいくつかの方法が提案されているが，ここでは
ウォータレベル法とマルチテーパ法およびその改良版の 時間拡張マルチテーパ法について少し詳しく説明する.

\section{1 ウォータレベル法}

（1）式の除算を安定化させるために，分母のスペク トルホールの小さい值をある一定值で置き換える手 法がウォータレベル法である [Helmberger and Wiggins (1971)].この手法はレシーバ関数を用いた多くの研究 で採用されてきた [例えば, Langston (1979), Owens et al. (1984)など].

Fig. 2b は，Fig. 2a に示す上下動成分波形のパワースペ クトルである、レシーバ関数解析で用いるマグニチュー ド 6 程度以上の遠地地震の $\mathrm{P}$ 波部分の卓越周期は数秒 以上である. また後述するように，レシーバ関数解析で は基本的な部分で水平成層構造を仮定しているために， 小規模不均質構造の影響を強く受ける短周期の波はカッ

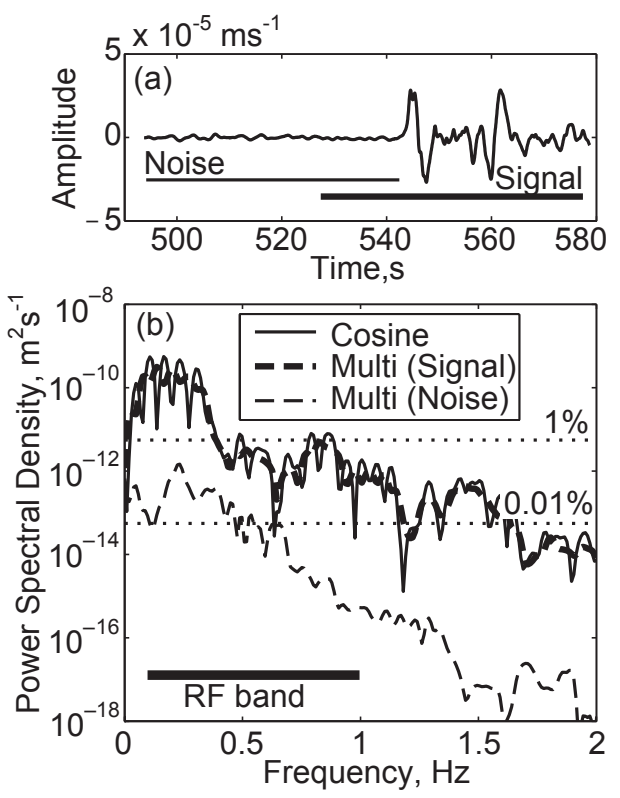

Fig. 2. (a) An example waveform of the vertical component of a seismogram observed at a station SK05 in the Kii Peninsula from an event of 0827 UT, 8 October 2004 whose moment magnitude is 6.8 and epicentral distance is $51.3^{\circ}$. The horizontal thick and thin lines show the time window for the signal and noise parts, respectively, in calculating the power spectra shown in (b). (b) Fourier spectra of the vertical seismogram shown in (a), calculated for the signal with a cosine taper (solid line) and a multitaper (thick dashed line), and for the noise with a multitaper (thin dashed line). The horizontal dotted lines show the water levels for $1 \%$ and $0.01 \%$ of the maximum value of the spectrum with the cosine taper. The horizontal thick line shows the frequency band of the receiver function calculation (see text for details). 
トする。このような事情からレシーバ関数解析における 周波数帯域は, Fig. $2 \mathrm{~b}$ の左下に太線で示すように, 0.1 〜 $1 \mathrm{~Hz}$ 程度となる. Fig. $2 \mathrm{~b}$ の実線は, 両端に時間長の $10 \%$ のコサインテーパをかけた場合であるが，スペク トル漏れによるスペクトルホールが多数見られる。これ らのスペクトルホールをパワースペクトルの最大值の 1 $\%$ のウォータレベル值で穴埋めする場合は，解析周波 数帯域の高い方の $2 / 3$ がほぼ埋まってしまい, 元の情報 を失うことになる. $0.01 \%$ のウォータレベル值で穴埋 めする場合は，解析周波数帯域全体で元のパワースペク トルの特徴は保持されるが，スペクトルホールはほとん ど埋まらず，除算の安定化は期待できない，このように ウォータレベル值は解析周波数帯域でのパワースペクト ルの形状により決定されなければならないが, 多数のレ シーバ関数を計算する場合には，これは実際上は困難で ある.

\section{2 マルチテーパ法}

スペクトル漏れによるスペクトルホールは，テー パのかけ方によって小さくすることができる. マル チテーパは，スペクトル漏孔を抑制する複数の prolate eigentaper から構成される [例えば, Park et al. (1987)]. この prolate eigentaper は DPSS (discrete prolate spheroidal sequences）サブルーチンにより計算することができる [例えば, Bell et al. (1993)]. Fig. 3a に示すマルチテーパ は, テーパ長 $T=50 \mathrm{~s}$, 時間 - 帯域幅積 $P=4$ として計 算されたものである．対応する固有值が 1 に近い低次側 の 3 つの prolate eigentaperを用いた。この場合, スペク トル漏孔を許す帯域幅は $2 P / T=0.16 \mathrm{~Hz}$ となる. 別の 言い方をすれば, このマルチテーパで算出されるスペク トルは, $0.16 \mathrm{~Hz}$ 程度の分解能で平滑化されることにな る. Fig. 2b の太破線はこのマルチテーパを用いて計算さ れたパワースペクトルである.コサインテーパで計算さ れた場合に比べ，スペクトルホールが小さいことがわか る.

Park and Levin (2000) はマルチテーパ法をレシーバ関 数の計算に導入した。 マルチテーパを用いたスペクトル 計算によりスペクトル漏れによるスペクトルホールを抑 え,さらに (1) 式の分母の上下動成分のパワースペクト ルに同成分の $\mathrm{P}$ 波に先行するノイズ部分のパワースペ クトルを加えることによりこの除算の安定化を図った。

しかし Fig. 3aに示すように，3つの prolate eigentaper に等価なテーパ (実線)にはフラットな部分がない。こ のことは, P 波のオンセットとマルチテーパのタイミン グに依存して，レシーバ関数の相対振幅が変化してしま う可能性があることを意味する.

\section{3 時間拡張マルチテーパ法}

Helffrich (2006) はマルチテーパ法を拡張して，任意 長の時間に対して正しい相対振幅をもつレシーバ関数 を算出する手法を提案した。 Shibutani et al. (2008) は Helffrich (2006) の手法の改良方法を提案した. Fig. 3aに 示すマルチテーパを $T / 4=12.5 \mathrm{~s}$ ずつずらして足し合わ せると，Fig. $3 \mathrm{~b}$ に実線で示すようなフラットな部分をも つテーパを作ることができる．このフラットな部分に $\mathrm{P}$ 波部分を納めれば，正しい相対振幅をもつレシーバ関数 を算出することができる，個々のマルチテーパに対応す るタイムウィンドについて計算されたスペクトルを足し 合わせる際には，タイムウィンドの遅延時間に対応する 位相の遅れを考慮して行う必要がある。

これまでに述べた 3 つの手法で計算されたレシーバ 関数の波形例を Fig. 4 に示す. $1 \%$ のウォータレベル值
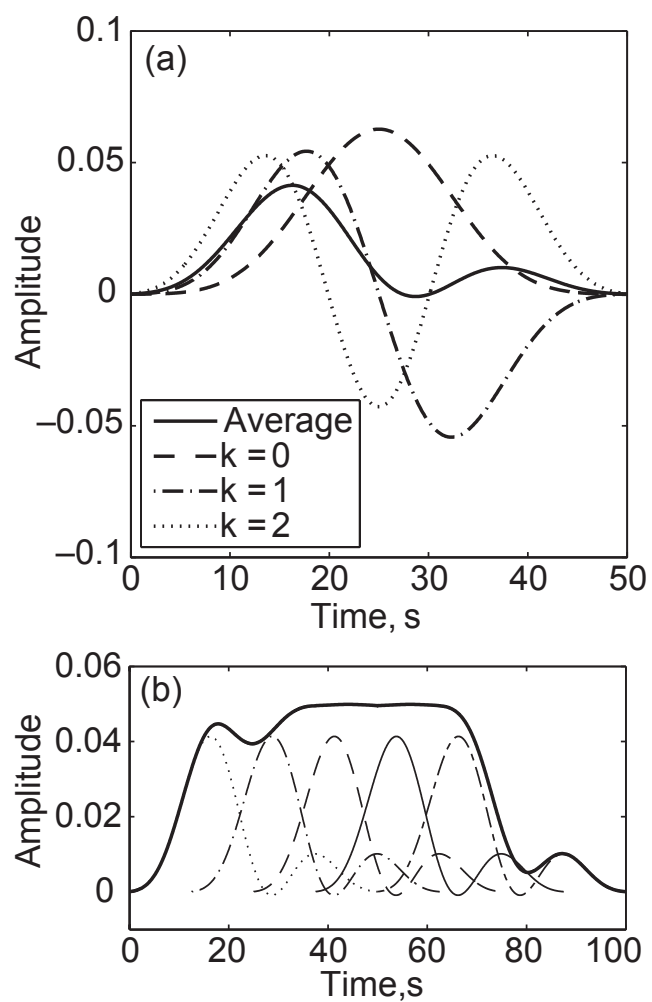

Fig. 3. (a) The three lowest-order $4 \pi$ prolate eigentapers with $50 \mathrm{~s}$ duration, the zero-th order (dashed line), the first order (dashed-dotted line) and the second order (dotted line). The solid line shows the multitaper generated by averaging the three eigentapers. (b) The five multitapers (dotted, dashed-dotted, dashed, solid, and long and short dashed lines) and the sum (thick solid line) used in this study. Each multitaper is the same as shown by the solid line in (a). The multitapers are summed with $75 \%$ window overlap. 

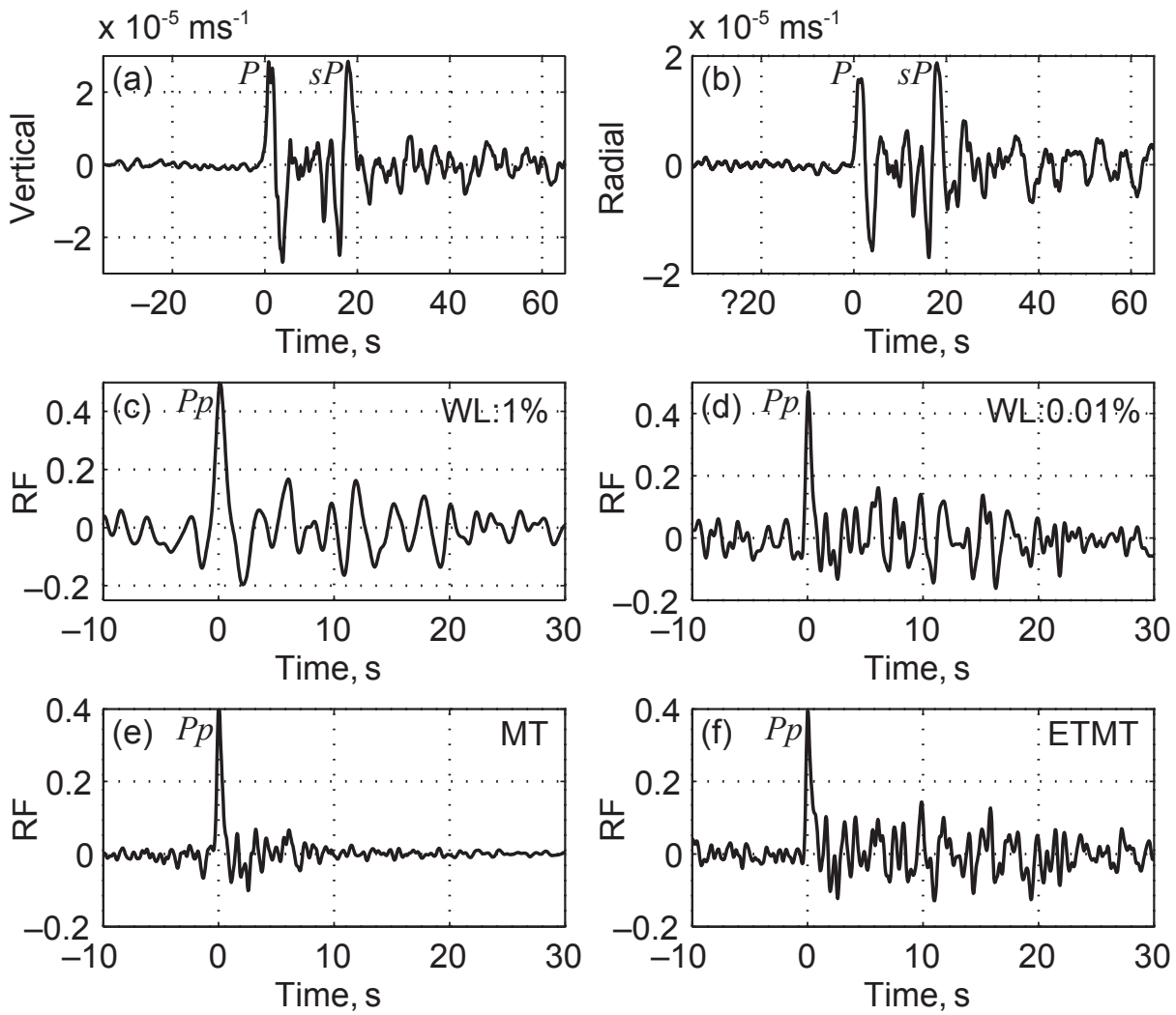

Fig. 4. Example waveforms of seismograms and receiver functions. (a) Vertical component of the seismogram shown in Fig. 2a. (b) Radial component of the same seismogram. (c) The receiver function calculated by deconvolving (a) from (b) with a water level of $1 \%$. (d) The receiver function calculated with a water level of $0.01 \%$. (e) The receiver function calculated by the multitaper method. (f) The receiver function calculated by the extended-time multitaper method.

を用いた場合 (Fig. 4c) では, 周波数が $0.4 \mathrm{~Hz}$ 程度より 高い波は含まれていない。これは，Fig. $2 \mathrm{~b}$ に示すょうに $0.4 \mathrm{~Hz}$ 以上の帯域でパワースペクトルがウォータレベ ル值に置き換えられてしまうためと考えられる．0.01\% のウォータレベル值を用いた場合（Fig. 4d）では，Ppに 先行するノイズ部分からわかるように $0.6 \mathrm{~Hz}$ 程度の波 が含まれている。これは， $0.6 \mathrm{~Hz}$ 付近にある深いスペク トルホール (Fig. $2 \mathrm{~b}$ の実線) によるものと思われる. マ ルチテーパ法の場合 (Fig. 4e) では, Pp から数秒間は時 間拡張マルチテーパ法の場合（Fig. 4f）と波形の対応を 見ることはできるが，振幅は過小評価されている，時間 拡張マルチテーパ法の場合, シグナル部分の波形は 0.01 \%のウォータレベル值の場合と対応をつけることがで き，振幅は $30 \mathrm{~s}$ 近くまで正しく評価されているとみな せる. $\mathrm{Pp}$ に先行する部分の振幅は小さく, ウォータレ ベル法の場合に見られるような特徵ある周波数の波が卓
越することもない.

\section{4 その他の方法}

Shiomi et al. (2004) は, 多変量自己回帰 (MAR) モデ ルに基づく方法によりレシーバ関数を計算した. 自己回 帰 (AR) モデルによるスペクトル推定は, FFTよりも高 い安定性と高い分解能をもっている. MAR モデルによ る方法では, レシーバ関数を安定的に求めるための係数 を AICに基づき自動的に設定することができる.ただし， この手法で計算されたレシーバ関数は, Pp からの相対 時間が $15 \mathrm{~s}$ を越えると, 振幅が小さくなる傾向がある [Shiomi et al. (2004)].

Gurrola et al. (1995) は, 上下動成分波形とレシーバ 関数のコンボリューションが水平動成分波形に等しいと いう関係を時間領域で連立一次方程式に書き下し，これ を減衰最小二乗法で解き，レシーバ関数を求めた。この 方法のダンピングパラメータは, 2.1 節で述べたウォー 
タレベル法におけるウォータレベル值と同様の働きをす る.

\section{§ 3. レシーバ関数インバージョン}

1 章で述べたように，レシーバ関数における PS 変換 波と直達 $\mathrm{P}$ 波の走時差は, 変換面の深さとその上の速 度構造によって決まり, それらの振幅比は, 変換面での 速度と密度の不連続量で決まる。したがって，レシーバ 関数を解くことによって, 観測点下の速度構造を推定す ることができる.

この逆問題は (2) 式のように定式化することができる.

$$
R_{i}\left(m_{1}, m_{2}, \cdots, m_{M}\right)=r_{i}, \quad i=1,2, \cdots, N
$$

ここに $m_{j}(j=1,2, \cdots, M)$ はモデルパラメータ, $R_{i}$ は理 論的に合成されたレシーバ関数， $r_{i}$ は観測波形から計算 されたレシーバ関数， $i$ は離散化された波形のサンプリ ングポイント番号である. 理論レシーバ関数の合成には, Generalized Ray Theory [Helmberger (1974)] や ThomsonHaskell 法 [Haskell (1962)] などが用いられる.

Owens et al. (1984) は, レシーバ関数のラジアル成分 を解いて, 水平成層モデルにおける $\mathrm{S}$ 波速度構造を推定 した。すなわち，(2) 式をある初期值のまわりで線形化 した後, 初期値の修正量についての連立一次方程式を最 小二乗法で解き, 初期值の更新を行い, これを（2）式の 残差の平方和が小さくなるまで繰り返すことにより，モ デルパラメータである $\mathrm{S}$ 波速度を求めた。

Ammon et al. (1990) は, レシーバ関数インバージョン において, 求められた不連続面の深さとその上の平均的 な速度にトレード・オフがあり, 解が一意的には決まら ない場合があることを指摘した，彼らは，数多くの初期 モデルに対してインバージョンを行い, 得られた解のう ち, レシーバ関数を, 誤差も考慮して, 説明できるすべ ての解を許容モデルとして扱うことが必要であると述心 ている.

Shibutani et al. (1996) は，遺伝アルゴリズム（GA）を レシーバ関数インバージョンに導入することにより, Ammon et al. (1990) の主張を効率よく実現する手法を提 案した，彼らの手法では，(2) 式を線形化することなく, 非線形のままで解けることも利点である，以下に，遺伝 アルゴリズムを用いたレシーバ関数インバージョンに関 して, オーストラリア大陸東部地域と四国東部地域に適 用した例について簡単に紹介する.

\section{1 オーストラリア大陸東部地域の地殼および最上 部マントルの構造}

Shibutani et al. (1996) は，オーストラリア大陸東部地 域に展開された 20 の臨時広帯域地震観測点において,
遺伝アルゴリズムを用いたレシーバ関数インバージョン により, 深さ $60 \mathrm{~km}$ までの水平成層の速度構造を推定し た.ランダムに生成した 50 個のモデルからなる初期集 団を選択, 交配, 変異という遺伝アルゴリズムのプロセ スを経て，200世代進化させた．個々のモデルの評価は (2) 式の残差の平方和の小ささで行った. このインバー ジョンでは 10,000 個のモデルが生成され, 評価される ことになるが, 彼らは, このうち上位 1,000 個程度のモ デルが, レシーバ関数の特徵を誤差範囲内で説明できる 許容モデルであることを示し，その分布に基づき，当該 地域の地款および最上部マントルの構造の特徵について 議論した.

オーストラリア大陸東部地域の褶曲帯は, 先カンブリ ア紀の安定地塊の東側に, 古生代に形成された。レシー バ関数インバージョンの結果は, 褶曲帯の軸に沿って地 殼が厚くなり, 地殼一マントル境界が遷移的になるとい う特徵を示した。 彼らは, この特徴を, マントル物質の 下部地殼への底付けあるいは貫入による褶曲帯における 地殼の成長を示すものであるとしている.

\section{2 四国東部地域の地殼およびスラブ構造}

涉谷 (2001) は, 四国東部の広帯域地震観測点 ISI に おけるレシーバ関数インバージョンの結果と, 同じく 四国東部で行われた人工地震観測のデータを組み合わ せて，当該地域下に沈み込むフィリピン海プレートの スラブとその上方の地殼の構造を推定した. ISI でのレ シーバ関数に見られる Pp から $2 \sim 3$ 秒後の後続波と 4 〜 秒後の後続波群をそれぞれ地殼中部と大陸モホ面 付近の速度不連続面でのPs とみなし, それらのPpに対 する相対振幅と相対走時の方位依存性 [例えば, Cassidy (1992)］から，速度不連続面の傾斜を推定した。これら の傾斜層を組み込んだモデルに対し，理論レシーバ関 数を Generalized Ray Theory [Helmberger (1974)] で計算 し, 遺伝アルゴリズムを用いてインバージョンを行った。 1,000 個のモデルからなる集団を 500 世代進化させ, 得 られたモデルのうち上位 10,000 個の許容モデルに基づ いて, ISI の下の速度構造を推定した。 このようにして ISI に対して推定された速度構造モデルを, 人工地震観 測の波形データにおける直達波, 屈折波および反射波な ぞの主な特徵を説明できるように，試行錯謂的に改良す ることにより, 四国東部地域の南北断面における 2 次元 構造モデルを推定した。

涉谷（2001）のモデルの特徵は，下部地殼（深さ 15 $25 \mathrm{~km})$ にくさび形の低速度層が存在することと, 大陸 モホ面が中央構造線の南側でスラブの上側にせり上がっ ていることである. 


\section{§4. レシーバ関数イメージング}

レシーバ関数の時間軸は, Pp と PS 変換波の走時差で あり, 変換面の深さとその上の速度構造で決まる. 逆に, 速度構造を仮定すれば，時間軸を深さ軸に変換すること ができる，1章で述べたように，PS 変換波にはPS とそ の多重反射波があるが,ここでは簡単のために振幅の いちばん大きな Ps のみを考慮することにする，さらに， 変換面が水平であると仮定すると, 深さ $z \mathrm{~km}$ の不連続 面で変換されたPs と Pp の走時差 $\Delta t_{P S}$ は (3) 式のように 表すことができる.

$$
\Delta t_{P S}(z)=\int_{0}^{z}\left(\sqrt{\beta(\zeta)^{-2}-p^{2}}-\sqrt{\alpha(\zeta)^{-2}-p^{2}}\right) d \zeta
$$

ここに, $p$ は波線パラメータ, $\alpha$ と $\beta$ はそれぞれ $\mathrm{P}$ 波 速度と $\mathrm{S}$ 波速度である. (3) 式から $z$ を $\Delta t_{P S}$ の関数とし て求め, その関係式を用いてレシーバ関数の時間軸を深 さ変換する.

$\mathrm{Ps}$ の変換点の軌跡は $\mathrm{S}$ 波の波線に一致するので, 波 線追跡によりそれを求め, イメージングを行う断面へ投 影する.これを多数の観測点で多数の地震に対して得ら れたレシーバ関数について行い, 断面上のピクセル内で 振幅を重合し，2次元のレシーバ関数イメージを作成す る. 1 章で述べたように，レシーバ関数に含まれる PS 変換波は基本的には $\mathrm{S}$ 波速度不連続量によって決まる ものであるから，このようにして得られたレシーバ関数 イメージは, $\mathrm{S}$ 波速度不連続面のイメージとみなすこと ができる.

以下に, レシーバ関数イメージングの研究例をいくつ か紹介する.

\section{1 近畿を縦断する新宮 - 京丹後測線のイメージ}

涉谷・伊藤 (2007) と北脇・他 (2007) は, 紀伊半島南 東端の和歌山県新宮市から丹後半島北西端の京都府京丹 後市までの近畿地方を縦断する測線（Fig. 5) において, レシーバ関数イメージングを行った。 この測線に沿うよ うに 35 の地震観測点を臨時的に展開し, 測線近傍の 13 の定常観測点とあわせて, 平均間隔が約 $5 \mathrm{~km}$ のリニア アレイを構築した. 2 年 7 か月の観測期間中に得られた 199 個の遠地地震に対して, 時間拡張マルチテーパ法に より全部で 5126 本のレシーバ関数を計算した。この波 形処理においては, 地震計の周波数特性を補正したのち, 通過帯域が $0.05 \sim 5.0 \mathrm{~Hz}$ のバンドパスフィルターを 適用した。速度構造として JMA2001 モデル [上野・他 (2002)］を用いて, 時間軸の深さ変換と波線追跡を行い, レシーバ関数を測線断面へ投影した. 断面を $1 \mathrm{~km} \times 1$ $\mathrm{km}$ のピクセルに分割し, 各ピクセルにおいてレシーバ 関数の振幅の重合を行った. Ps の変換点が断面から 10 $\mathrm{km}$ 以上離れる場合は, その距離に応じて重合における 重みを小さくして, 断面に直交する方向の不均質構造の 影響を抑えた。

得られたレシーバ関数イメージを Fig. 6 に示す. 赤い ピクセルはレシーバ関数の正の振幅を示し, その連なり は高速度層の上面を表す。青いピクセルは負の振幅を示 し，その連なりは低速度層の上面を表す。

紀伊半島の南東端 (Fig. 6 のイメージの右端) の深さ $25 \mathrm{~km}$ から大阪平野南端の梁さ $75 \mathrm{~km}$ まで北西下がり （左下がり）に赤いピクセルが連なっているが, これは 沈み込むフィリピン海プレートの海洋モホ面と考えられ る.その上方 $5 \mathrm{~km}$ にほぼ平行に青いピクセルの連なり が見られるが, これは低速度である海洋地殼の上面と考 えられる. 沈み込んだ海洋地殼が深さ $30 \sim 40 \mathrm{~km}$ に達 するところで深部低周波イベントが発生しているが，こ れには海洋地壳から脱水分解により放出された「水」が 関与しているものと考えられる [Obara (2002), 鎌谷・

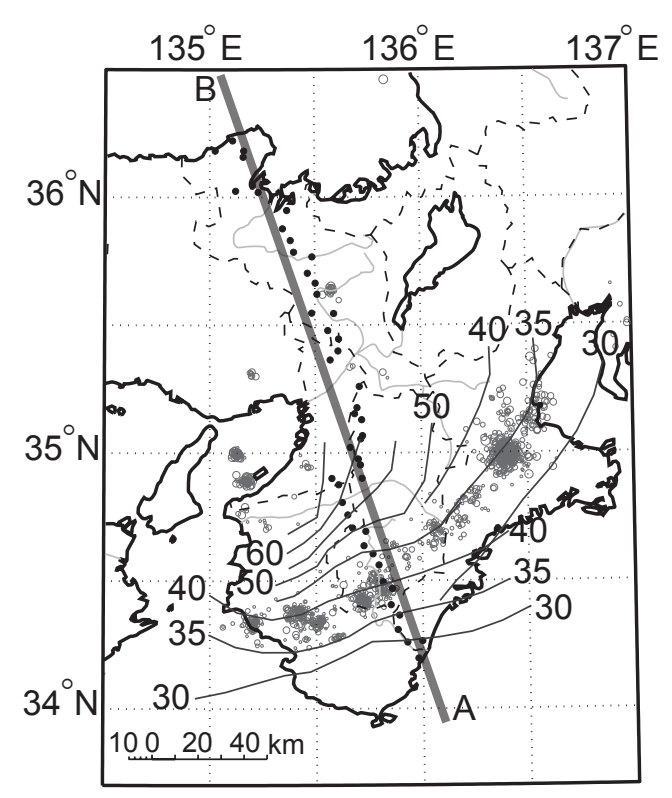

Fig. 5. Distribution of seismic stations (solid circles) and a profile line (thick gray line). The stations were distributed in $\sim 5-\mathrm{km}$ interval from Shingu, Wakayama to Kyotango, Kyoto, including 35 temporary stations and 13 permanent stations near the line. A receiver function image on the cross-section along the line $\mathrm{AB}$ is shown in Fig. 6. Open circles denote deep low frequency events determined by the Japan Meteorological Agency (JMA). Thin lines indicate the isodepth contours of the upper surface of the Philippine Sea Plate estimated by Miyoshi and Ishibashi (2004). The numerals at the contours denote the depth in $\mathrm{km}$. 


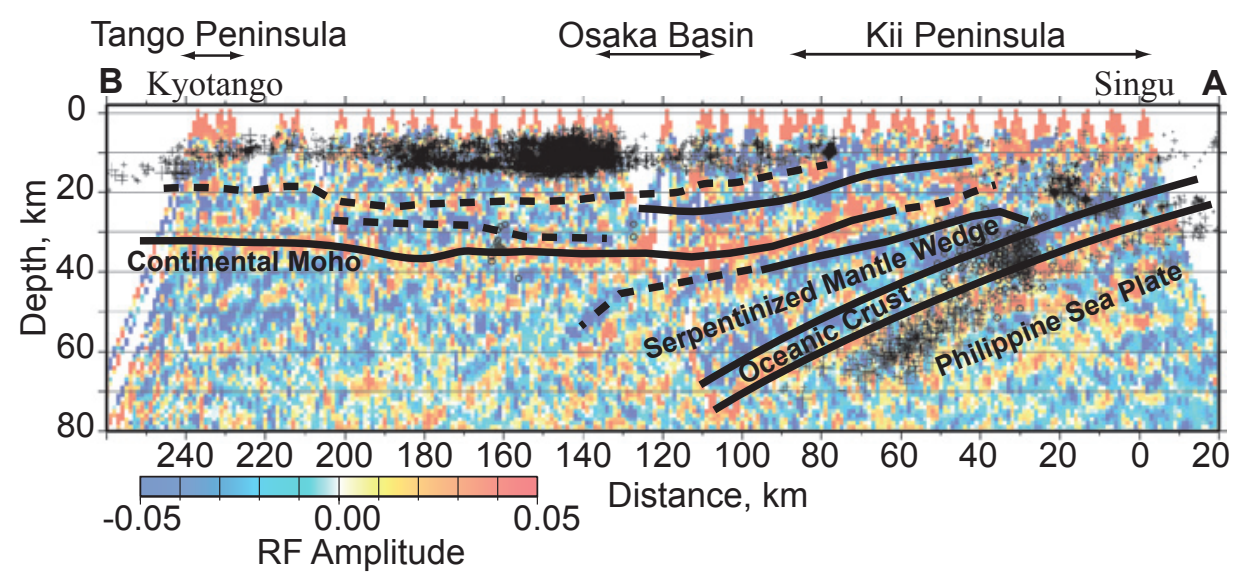

Fig. 6. Receiver function image on the cross-section along the profile line AB in Fig. 5. The origin of the horizontal axis is located at the intersection of the line $\mathrm{AB}$ and the coast line of the Kii Peninsula. The positive amplitudes of the receiver functions are plotted with warm colors, while the negative amplitudes are plotted with cold colors. Open circles are deep low frequency events and crosses are ordinary earthquakes, both of which are determined by JMA. The solid and broken lines indicate, respectively, clear and unclear seismic velocity discontinuities estimated in this study.

勝間田 (2004)]. この「水」は周辺のマントルウェッジ 内でかんらん岩を蛇紋岩化する，蛇紋岩化したマントル ウェッジは低速度であり，その上面は Fig. 6 において青 いピクセルの連なりとして認めることができる。また， 蛇紋岩は強度も小さく, 蛇紋岩化したマントルウェッジ の上端がプレート境界の固着域の下限を決めると考えら れる [Bostock et al. (2002)].

一方, 丹後半島の北西端 (Fig. 6 のイメージの左端) の 深さ約 $30 \mathrm{~km}$ から大阪平野の梁さ $35 \mathrm{~km}$ までやや南東 下がり（右下がり）に赤いピクセルが連なっているが, これは大陸モホ面であると考えられる。この赤いピクセ ルの連なりは, 大阪平野の南端から紀伊半島にかけて, 南東方向にせり上がっているように見える.

\section{2 四国東部〜中国地方北部地域のイメージ}

Ueno et al. (2008) は，2002 年から 2004 年にかけて行 われた西南日本合同観測 [西南日本大学合同地震観測グ ループ (2002)] のデータとその周辺の定常観測点のデー 夕を用いて，四国東部から中国地方北部にかけての地域 のレシーバ関数イメージを求めた.

室戸岬から島根半島に至る南南東 - 北北西の断面に押 けるイメージには, 四国東部から中国地方南部にかけて の地域に，北北西に緩やかに傾斜する明瞭な赤いピクセ ルの連なりが見られる。これは高速度層の上面であるが, 彼らは，これをフィリピン海プレートの海洋地殼内の速 度不連続面に対応するものと解釈した。

中国地方北部では, 深さ $30 \mathrm{~km}$ 付近に大陸モホ面と 考えられる赫いピクセルの連なりが見られた。さらにそ
の下方の深さ 50 〜 $60 \mathrm{~km}$ にもやや不明瞭ではあるが, 不連続面が検出された。彼らは, この不連続面を,イメー ジの連続性から, 非地震性のフィリピン海プレートに対 応するものと考えた。西田・他 (2002) によって行われ た 2000 年鳥取県西部地震の震源域での人工地震探査の 結果や Doi and Nishigami (2007) による 2000 年鳥取県西 部地震稠密余震観測データを用いた反射法解析の結果に 押いても，深さ $50 \sim 60 \mathrm{~km}$ に反射体が検出されていて， これは, 上述のレシーバ関数解析で検出された不連続面 に対応するものと考えられる。

\section{3 その他の研究}

Yamauchi et al. (2003) と Shiomi et al. (2004) は, 定常 観測点のデータを用いて, 中・四国から近畿にかけての 地域に打いてレシーバ関数イメージングを行い，当該地 域の下に沈みこんでいるフィリピン海プレートの形状を 推定し, 中国地方の下にも非地震性のスラブが存在する 可能性を示した.

Tonegawa et al. (2006a) と Kawakatsu and Watada (2007) は，定常観測点のデータを用いて，東北日本下に沈み 込む太平洋プレートのレシーバ関数イメージを求めた。 Tonegawa et al. (2006a) は，プレート上面と海洋モホ面 が深さ $120 \mathrm{~km}$ までイメージできること, また太平洋ス ラブの下面が深さ $200 \mathrm{~km}$ まで検出できることを示した.

Kawakatsu and Watada (2007) は，90 km 以深でレシー バ関数の正の振幅の連なりが 2 本存在することを発見し た。彼らは, 深い方をその連続性から海洋モ木面と考え, 浅い方を低速度の蛇紋岩層の下面と推定した。 
これまで紹介した研究は, 高密度に展開された短周 期地震計の地震波形を用いたものであった。しかし，レ シーバ関数解析における周波数帯域 $(0.1 \sim 1 \mathrm{~Hz}$ 程度 $)$ は短周期地震計の周波数特性のフラットな帯域の低周波 側の外側になる. Tonegawa et al. (2006b) は，低周波側 にも感度を有し， かつ観測点密度の高い高感度加速度計 と広帯域地震計の波形データを用いた斬新な解析手法を 考案し, 日本列島下に沈み込む太平洋プレートおよび $410 \mathrm{~km}$ 不連続面と $660 \mathrm{~km}$ 不連続面を明瞭にイメージす ることに成功した。

最後に，国外の研究を紹介する. Gossler et al. (1999) は, ドイツ北部からスウェーデン南部にかかる地域で行 われた測線長約 $800 \mathrm{~km}$ のアレイ観測のデータを用いて レシーバ関数イメージングを行い, 先カンブリア代のバ ルト楯状地と顕生代のドイツ北部地域が接している当該 地域の地殻構造についての研究を行った. 彼らの結果に は大陸モホ面が明瞭にイメージされていて, 反射法地震 探査イメージとの対応が良い. 大陸モホ面はバルト楯状 地の縁辺部から中心部へ向かう方向に深くなっていて, 高速度の地殼が厚くなっているものと解釈された。

Rondenay et al. (2001) と Bostock et al. (2002) は, 逆 散乱理論に基づく新しいイメージング手法を用いて，カ スケード沈み込み帯南部のマントルウェッジの構造を求 めた。 彼らの手法は, 遠地地震からの入射波の前方散乱 波と地表反射波の後方散乱波の逆射影を行って，2次元 不均質構造を推定するというものであり，水平な変換面 は仮定されていない. 彼らの結果では, 沈み込むファン デフカプレートの海洋地殼は深さ約 $40 \mathrm{~km}$ までは顕著な 低速度を示し, その近傍のマントルウェッジは上方にあ る大陸地殼よりも低速度である. 深さ $40 \mathrm{~km}$ 付近で海洋 地殼からの脱水が起こり, 放出された「水」により近傍 のマントルウェッジが蛇紋岩化され, 低速度となったと 解釈された.この結果と 4.1 節で述べた紀伊半島下のフィ リピン海プレートとその近傍のマントルウェッジの構造 との間には共通点が認められる.

\section{$\S 5$. 今後の展望}

これまでのレシーバ関数解析では，インバージョンで もイメージングでも基本的に水平成層構造を仮定し， ラ ジアル成分のみを扱う研究がほとんどである。しかし, 実際の地球の構造では, 沈み込むプレートのように傾斜 した不連続面もあれば，いろいろなスケールでの 3 次 元不均質も存在する. 3.2 節で触れたように, 傾斜した 不連続面で生成される Ps の Pp に対する相対走時には方 位依存性がある [例えば, Cassidy (1992)] ので, レシー バ関数の深さ変換と変換点のマッピングにおいては到来
方向を考慮して行うことが必要になる. また, 水平成層 構造であっても媒質が異方性をもつ場合は, Ps の Ppに 対する相対走時と相対振幅に方位依存性が生じる [例え ば, Levin and Park (1998), Park et al. (2004)].さらに, 傾斜した不連続面や 3 次元不均質や異方性媒質の場合 は，トランスバース成分にも構造に起因する波相が現れ ることになる. Hirahara (2006) は，3 次元構造モデルに 対してガウシアンビーム法で合成した理論波形と比較す ることにより, 紀伊半島で得られたレシーバ関数 [澁谷・ 伊藤 (2007)] のトランスバース成分波形にフィリピン 海プレート上面で変換したPs が同定できる可能性を示 した. 今後のレシーバ関数解析は, ラジアル成分だけで はなく, トランスバース成分も利用して，3 次元的な構 造のモデリングを目指すべきであると考える.

\section{謝辞}

本論文執筆の機会をお与えくださった特集号編集委 員の皆様に感謝いたします。查読過程で多くの有用な意 見をいただきました汐見勝彦氏と匿名の査読者および編 集担当委員の青柳恭平氏に感謝いたします.

\section{文献}

Ammon, C. J., 1991, The isolation of receiver effects from teleseismic P waveforms, Bull. Seism. Soc. Am., 81, 2504-2510.

Ammon, C. J., G. E. Randall, and G. Zandt, 1990, On the nonuniqueness of receiver function inversions, J. Geophys. Res., 95, 15303-15318.

Bell, B., D. B. Percival, and A. T. Walden, 1993, Calculating Thomson's spectral multitapers by inverse iteration, J. Comput. Graph. Stat., 2, 119-130.

Bostock, M. G., R. D. Hyndmann, S. Rondenay, and S. M. Peacock, 2002, An inverted continental Moho and serpentinization of the forearc mantle, Nature, 417, 536-538.

Cassidy, J., 1992, Numerical experiments in broadband receiver function analysis, Bull. Seism. Soc. Am., 82, 1453-1474.

Doi, I. and K. Nishigami, 2007, Three-dimensional distributions of $\mathrm{S}$ wave reflectors in the source region of the 2000 Western Tottori Earthquake, Geophys. Res. Lett., 34, L20312, doi:10.1029/2007GL031169.

Gossler, J., R. Kind, S. V. Sobolev, H. Kämpf, K. Wylegalla, M. Stiller, and TOR Working Group, 1999, Major crustal features between the Harz Mountains and the Baltic Shield derived from receiver functions, Tectonophysics, 314, 321-333.

Gurrola, H., G. E. Baker, and J. B. Minster, 1995, Simultaneous time-domain deconvolution with application to the computation of receiver functions, Geophys. J. Int., 120, 537-543.

Haskell, N. A., 1962, Crustal reflection of plane P and SV waves, J. Geophys. Res., 67, 4751-4767. 
Helffrich, G., 2006, Extended-time multitaper frequency domain cross-correlation receiver-function estimation, Bull. Seism. Soc. Am., 96, 344-347.

Helmberger, D. V., 1974, Generalized ray theory for shear dislocations, Bull. Seism. Soc. Am., 64, 45-64.

Helmberger, D. and R. Wiggins, 1971, Upper mantle structure of midwestern United States, J. Geophys. Res., 76, 3229-3245.

Hirahara, K., 2006, Toward receiver function tomography, EOS Trans. Am. Geophys. Union, 87, Fall Meet. Suppl., Abstract S54B-07.

鎌谷紀子・勝間田明男，2004，火山から離れた地域で発 生している深部低周波微動・地震 - その分布と発生 原因一, 地震 $2, \mathbf{5 7}, \mathbf{1 1 - 2 8}$.

Kawakatsu, H. and S. Watada, 2007, Seismic evidence for deep-water transportation in the mantle, Science, 316, 1468-1471.

北脇裕太 - 涉谷拓郎 - 西村和浩 - 中尾節郎 - 福嶋麻沙代 三浦 勉 - 伊藤 潔 - 大見士朗 - 小河和雄 - 平原和朗, 2007, 紀伊半島下のフィリピン海プレートと蛇紋岩化 マントルウェッジ，地震学会講演予稿集 2007 年度秋 季大会, P2-087.

Langston, C. A., 1979, Structure under Mount Rainier, Washington, inferred from teleseismic body waves, J. Geophys. Res., 84, 4749-4762.

Langston, C. A. and J. K. Hammer, 2001, The vertical component P-wave receiver function, Bull. Seism. Soc. Am., 91, 1805-1819.

Levin, V. and J. Park, 1998, P-SH conversions in layered media with hexagonally symmetric anisotropy: A CookBook, Pure Appl. Geophys., 151, 669-697.

三好崇之・石橋克彦, 2004, 震源分布から見た伊勢湾か ら四国西部にかけてのフィリピン海スラブの形状，地 震 $2, \mathbf{5 7}, \mathbf{1 3 9}-152$.

西田良平・平田 直 - 伊藤 潔 ・梅田康弘 - 井川 猛 大西正純, 2002 , 鳥取県西部地域の地下構造調査 (その 1), 地震学会予稿集 2002 年度秋季大会, P062.

Obara, K., 2002, Nonvolcanic deep tremor associated with subduction in southwest Japan, Science, 296, 1679-1681.

Owens, T. J., G. Zandt, and S. R. Taylor, 1984, Seismic evidence for an ancient rift beneath the Cumberland Plateau, Tennessee: A detailed analysis of broadband teleseismic $\mathrm{P}$ waveforms, J. Geophys. Res., 89, 7783-7795.

Park, J. and V. Levin, 2000, Receiver function from multipletaper spectral correlation estimates, Bull. Seism. Soc. Am., 90, 1507-1520.

Park, J., C. R. Lindberg, and F. L. Vernon III, 1987, Multitaper spectral analysis of high-frequency seismograms, J. Geophys.
Res., 92, 12675-12684.

Park, J., H. Yuan, and V. Levin, 2004, Subduction zone anisotropy beneath Corvallis, Oregon: A serpentinite skid mark of trench-parallel terrane migration?, J. Geophys. Res., 109, B10306, doi:10.1029/2003JB002718.

Rondenay, S., M. G. Bostock, and J. Shragge, 2001, Multiparameter two-dimensional inversion of scattered teleseismic body waves 3. Application to the Cascadia 1993 data set, J. Geophys. Res., 106, 30795-30807.

西南日本大学合同地震観測グループ，2002, 西南日本に おりる大学合同地震観測, 地震学会予稿集 2002 年度 秋季大会, P004.

涉谷拓郎，2001，レシーバ関数解析による四国東部地域 の地殼およびスラブ構造, 月刊地球, 23, 708-713.

涉谷拓郎・伊藤 潔, 2007, 自然地震による地殼構造探 査 (近畿圈), 大都市大震災軽減化特別プロジェクト I 地震動 (強い摇孔) の予測「大都市圈地殼構造調査研 究」(平成 18 年度) 成果報告書, 294-302.

Shibutani, T., M. Sambridge, and B. Kennett, 1996, Genetic algorithm inversion for receiver functions with application to crust and uppermost mantle structure beneath Eastern Australia, Geophys. Res. Lett., 23, 1829-1823.

Shibutani, T., T. Ueno, and K. Hirahara, 2008, Improvement in the extended-time multitaper receiver function estimation technique, Bull. Seism. Soc. Am., 98, 812-816.

Shiomi, K., H. Sato, K. Obara, and M. Ohtake, 2004, Configuration of subducting Philippine Sea plate beneath southwest Japan revealed from receiver function analysis based on the multivariate autoregressive model, J. Geophys. Res., 109, B04308, doi:10.1029/2003JB002774.

Tonegawa, T., K. Hirahara, T. Shibutani, and N. Fujii, 2006a, Lower slab boundary in the Japan subduction zone, Earth Planet. Sci. Lett., 247, 101-107.

Tonegawa, T., K. Hirahara, T. Shibutani, and K. Shiomi, 2006b, Upper mantle imaging beneath the Japan Islands by Hi-net tiltmeter recordings, Earth Planets Space, 58, 1007-1012.

上野 寛 - 畠山信一 - 明田川 保 - 舟崎 淳 - 浜田信生, 2002 , 気象庁の震源決定方法の改善 - 浅部速度構造と 重み関数の改良一, 験震時報, 65, 1507-1520.

Ueno, T., T. Shibutani, and K. Ito, 2008, Subsurface structures derived from receiver function analysis and relation to hypocenter distributions in the region from the eastern Shikoku to the northern Chugoku districts, Southwest Japan, Earth Planets Space, 60, 573-579.

Yamauchi, M., K. Hirahara and T. Shibutani, 2003, High resolution receiver function imaging of the seismic velocity discontinuities in the crust and the uppermost mantle beneath southwest Japan, Earth Planets Space, 55, 59-64. 